\title{
Impact of Political Education to the Participation of Beginner Voters in General Election
}

\author{
$1^{\text {st }}$ Pebriyenni* \\ Dep. of Civic Education, \\ Universitas Bung Hatta, Padang, Indonesia \\ pebriyenni@bunghatta.ac.id
}

\author{
$2^{\text {nd }}$ Azwar Ananda \\ Dep. of Civic Education, \\ Universitas Negeri Padang, Padang, Indonesia \\ $3^{\text {rd }}$ Nurhizrah Gistituati \\ Dep. of Education Administration, \\ Universitas Negeri Padang, Padang, Indonesia
}

\begin{abstract}
This research is triggered by the facts that there were 360 election dispute reports submitted to the Constitutional Court and 15,052 findings by Election Supervisory Body in 2019 General Election. Meanshile, voters participation rate was recorded high, namely at $81.93 \%$. This phenomenon is interesting to be further examined so that it can be proven whether the understanding to political education and education levels can influence the participation quality in an election. The population of this research are 1377 beginner voters spread in 31 polling stations in Pasar Ambacang Village, Kuranji Sub=District, Padang City, West Sumatra. The sample was drawn stratified random sampling technique with a sample size of 138 in number. The research instrument was in the form of questionnaire. The data were analyzed with two-way Anava statistics. The
\end{abstract}

\section{INTRODUCTION}

Political literacy is defined as the ability of an individual to make political choice and to give opinion, to be aware of his/her rights, and to have knowledge on state governance, regulations, and autonomous aspects in life [1]. Political literacy plays an important role in a democratic process, and is acquired through political education. Citizens may become ignorance of democracy if they have lack of knowledge on political issues and political activities. In a country with democratic system, general election (election) serves as a means for results of the study found that the significance value of the understanding to political education is smaller than 0.01 , which means that there are differences in the political participation quality of beginner voters with the level of understanding of political education. Furthermore, the significance value of the level of education is $\mathbf{0 . 4 5 4}$, which means it is greater than 0.01 . It shows that there is no difference in political participation quality of beginner voters with the level of education. Significance value obtained for the understanding of political education at ${ }^{*}$ the level of education is 0.811 which means greater than 0.01 . It shows that there is no interaction between the understanding of political education and education level in influencing the voter participation quality.

Keywords-Political Education, Beginner Voters, General Election Participation the people to express their political aspirations. Democracy and Election are intrinsically related to each other because it is the elections that build the democracy. In Indonesia the provisions on Elections are set forth in Article $22 \mathrm{E}$ of the 1945 Constitution of the Republic of Indonesia, and in the Law of the Republic of Indonesia Number 7 of 2017.

Democratically-elected goverment shall be formed if the voters can exercise their respective individual rights by voting freely and without any duress from any party whomsoever [2], [1]. Election results in 
Indonesia in 2019 showed that the participation level of the voters reached $81.93 \%$, which was considerably high, in which the number of legitimate votes for legislative election (DPR) amounted to 139.970 .810 votes, and for presidential election amounted to 154.257.601 votes [3]. These data prove that quantitatively the participation level of the voters was very high.

The problem highlighted in this Research is the quality of the Election in terms of voters, legislative candidates, and election organizers. There were 360 election disputes being reported to the Constitutional Court, 260 reports of which had been brought to trial [3]. Similarly [4] received 15.052 findings, whether criminal, administrative, or non criminal nor administrative. In addition, almost all media in their coverage reported about the tendency of the public to be easily influenced by untrue and misleading information so called hoaxes. All the above have tarnished the quality of the Election. In view of the problem above, this research would like to seek the solution and for such purpose formulate the problem as follows: "how political education influences the participation of beginner voters in general elections".

The objective of this research is to describe the impact of political education on the participation of beginner voters in general elections. The urgency of this research is to create quality elections in such a way that it shall give impact on sovereign governance. Earlier researches concluded that reasonable voters may be improved, in terms of their quality and quantity, through political education either in formal education (Civic) or non-formal education [1]. In this matter, the most important political literacy is the understanding on nationality and statehood and knowledge of elections. In the perspective of good citizens, political education is a process of stimulating the citizens to have initiative to seek adequate information, insights, and political skills.

With political literacy, voters will be able to think critically and encourage them to create a climate of healthy and democratic social, national and state life [5]. Political education is part of adult education, which is directed to the effort to foster individual abilities. It is aimed at self-actualization as autonomous free individuals in developing their social dimensions and related to their position as citizens [5]. Refer to political education as public education, which is an effort to involve citizens in a community to create a culture of participation, political education will give voters awareness to use their vote [6]. Similarly [5], stated that political education is often termed as political forming or politishe bildung. Forming means creating political persons who are aware of their political status and position in the community. While bildung refers to self-forming activities with full awareness of the responsibility to become a political person. It can be concluded that political education is a deliberate and systematic effort to shape individuals who have political awareness, ethically or morally responsible in achieving political goals (good citizens).

There are three aspects of political education, namely cognitive, affective, and psychomotor aspects [5], [7]. Firstly, the Cognitive Aspect, it suggests that political education contributes to the building of political knowledge of citizens. When the intelligence of a leader can not be matched by the intelligence and knowledge of the people it may lead to disorderliness. The lack of political literacy in society may produce dictatorial leaders [1]. Secondly, the Affective Aspect, it serves as the aspect that contribute to the building of character and preference of citizens. Affective process is a process of introducing and instilling values to shape the political character and preference of the citizens and implement them in life. Thirdly, the Psychomotor Aspect, it contributes to the building of citizens' skills which includes intellectual and participatory skills. Intellectual skill is a critical thinking skill. Including in this skill is the ability to hear, identify and describe problems, analyze, and conduct an evaluation of public issues. Participatory skill includes the ability to interact, the ability to monitor public issues, and the ability to influence public policy. The three aspects of political education above in the realm of democracy may contribute to the creation of smart and ideal citizens [8], [9], [10] 
[11]. There are five rational criteria for voters: (1). Individuals can make a decision when facing with a series of alternative choices; (2) Individuals can arrange their own preferences with the choices available in sequence; (3) The arrangement of these preferences is transitive; (4) Individuals choose the closest/main alternative; and (5) If faced with various choices at different times in the same environment, individuals will make similar decision. All the above can be simply described as: the voter who not only has electoral knowledge and awareness, but is also free from any kind of intimidation, and has resistance to transactional politics.

Furthermore, as a means of implementing people's sovereignty, ideally an election should not only be attended by a large number of voters (quantity) for achieving high participation rate, but also must be held in a competitive, transparent, fair and accountable atmosphere (quality) so that it can produce leaders of choices who are politically competent and having full integrity. To create qualified elections with quality participation requires certain preconditions, among others the performance of voters who are politically literate, intelligent and critical in such a way that their political preferences shall be rational (rational choice). Political participation of the people influences the legitimacy of a government [12]. Political participation of the voters in elections can be regarded as the means for the public to evaluate and control the leaders or the government. Political participation is driven mainly by intrinsic motivation related to selfefficacy and empowerment, so that the people will have the bargaining power to influence the decision makers [13].

Participation can be done spontaneously, continuously or sporadically, peacefully or violently, legally or illegally, effectively or ineffectively [14]. To understand the level of participation it can be seen from two approaches, namely Contextual Approach (socio-economic and political environment) and Individual Sociological Approach. The Contextual Approach assumes that the political action of a person or a group of people is strongly influenced by their socio-economic status, their position in the production process (social class) or the existing political structure. As for the Individual-Sociological Approach, it is divided into two sub-approaches, namely by: (a) seeing the political behavior as an unintentional activity (unconscious of the goal), or seeing the political behavior as a result of psychological factors that influence political actors at the unconscious level; and (b) seeing the political behavior as a conscious effort to achieve certain goals (intentional) [14]. There are three approaches/models (schools of thought) being used in the study of voting behavior/political participation [9], [11], namely Sociological Model, Psychological Model, and Rational Choice Model. Sociological Model is the first approach which basically assumes that every human being is bound by various social circles, such as family, workplace, neighborhood, and so on. Every individual is encouraged to make self-adjustment in such a way that his/her behavior shall be accepted by surrounding social environment. The voting behavior of a person tends to follow the direction of political predisposition of the social environment where he/she lives. There are three main factors as the earliest index of this approach, namely: socioeconomic status, religion, and domicile.

Second, Psychological Model, which is the approach related to (a) personal perceptions and discernment against candidates; (b) personal perceptions and discernment against issues being raised; and (c) identification to political parties or partisanship. According to this approach, the factors that directly influence voter's choices are short-term factor and longterm factor affecting the voters. Particular issues may influence voter's behavior only if such issues can be understood by the voters; or the issues are deemed important; or the voters have share interest on the issues, either positively or negatively. Third, Rational Choice Model. This approach views that elections are like a market, which requires supply (political parties) and demand (voters). Rational choice theory criteria assumes that individuals have information that enables them to make choices. In an election, such an information will lead the voters to compare the benefits that can be given by each political party or candidate if they assume the power. The segment of voters that 
needs to be considered in an election is the beginner voters [11]. [16] Beginner voters are the constituents who have met the requirements, take part in the election for the first time and mostly have the status as students, university students or youths with an age range of 17-21 years.

\section{METHOD}

This research is a descriptive correlational research by adopting sequential explanatory method. The subjects of the research are all voters registered in the permanent voters list in Pasar Ambacang Village, Kuranji Sub-District, Padang City, West Sumatra, Indonesia, consisting of 10.893 inhabitants. The population of this research was all the beginner voters in the areas, namely 1377 voters who spread across 31 polling stations (TPS), consisting of 616 beginner voters with education level under or equal to Senior High School, and 761 beginner voters at university level education. The samples were collected in two stages: the first stage was done by cluster sampling techniques, and the second stage was done by stratified random sampling techniques. At the first stage, the samples were taken by way of cluster sampling method and originated from 31 polling stations which represented the beginner voters having education level under or equal to Senior High School, as well as those having university education level. At the second stage, the samples were taken by way of proportioned stratified random sampling method, using the Slovin Formula, with a standard error of $10 \%$. Among 138 samples, 67 of which were men and 71 were women. The data were collected using questionnaire research instrument. Data analysis was processed at several stages: a) data coding, b) data cleaning, c) data presenting/output, and d) data analyzing. The results of data processing were presented in the form of numbers; graphics and pictures/figures. Furthermore, the data was analyzed quantitatively by applying two-way ANAVA statistical analysis by firstly conducting normality test and variance homogeneity test.

\section{RESULTS AND DISCUSSION}

The results of this research answer the hypothesis regarding the impact of educational level and understanding of political education to the quality of voters in general elections, and the interaction between the level of education and the political education in influencing the quality of voters participation. In simple terms it can be stated that qualified voters are those who not only have electoral knowledge and awareness, but are also free from any forms of intimidation, and have resilience to transactional politics. The data for this research were obtained from 138 respondents of the beginner voters in 31 polling stations in Pasar Ambacang Village, Kalumbuk District, Padang, West Sumatra. The respondents aged between 17 to 21 years, 56 of whom were university students and 82 others have an educational backgroud of junior or senior high schools or equivalent. Political education is a systematic effort, both formal and informal, aimed at creating individuals who are politically concious and accountable, ethically or morally, in achieving political goals (good citizens). In order to detect the level of understanding of the respondents to political education, the researcher distributed questionaires and obtained data from the answers given to 20 items of questions which were categorized into five aspects, namely understanding of the pillars of diversity (Pancasila, the 1945 Constitution, Unity in Diversity and the Unitary State of the Republic of Indonesia), and groups of questions related to general election procedures. With regard to the quality of participations, the researcher had received the answers for five questions related to rationality of the voters in making their choices. Figure 1 below explains the level of understanding of the beginner voters towards political education: 


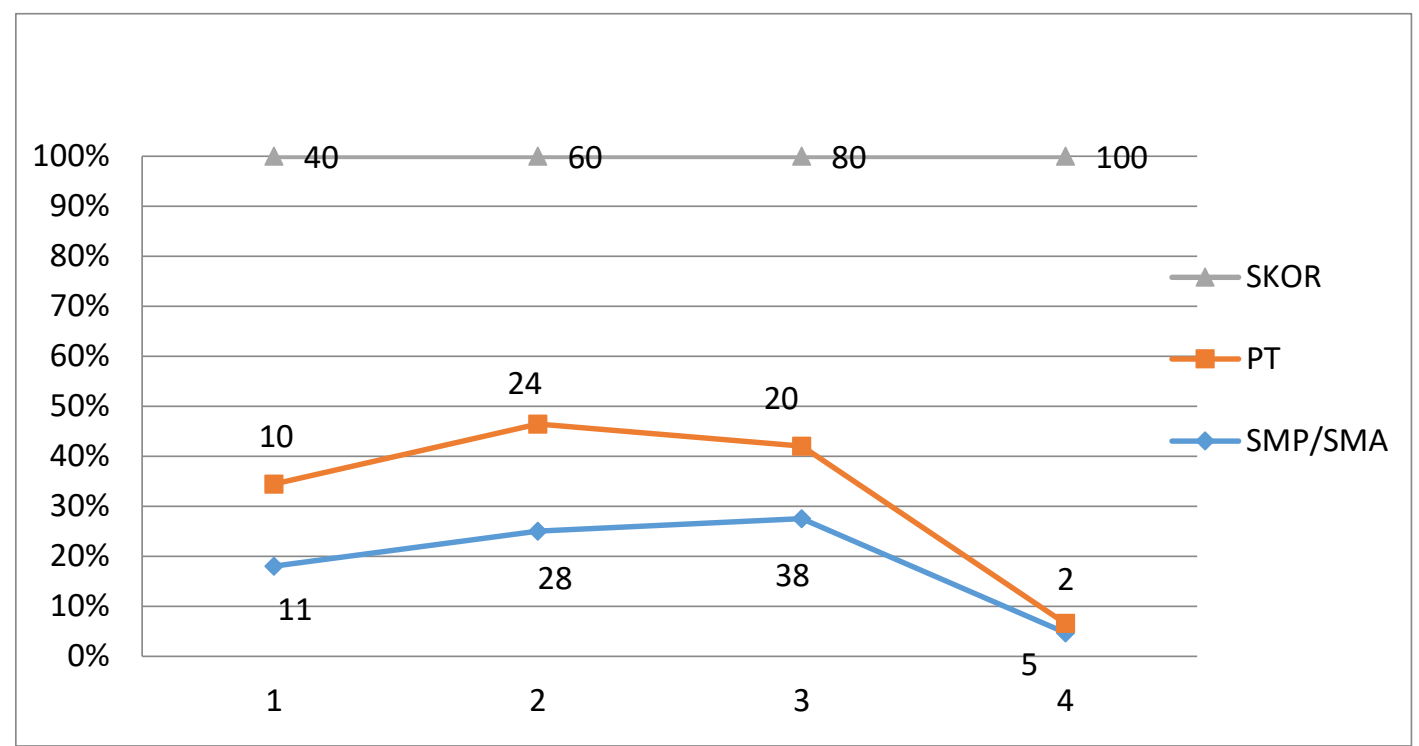

Figure 1. Level of Understanding to Political Education Among Beginner Voters

Figure 1 explains that out of 138 respondents $47,10 \%$ of whom had better understanding of political education, and $15,21 \%$ were in low understanding category. If viewed from the level of formal education it was found that it did not directly affect the political understanding and the quality of participation of the respondent in the election. The data shows that $39,29 \%$ of the voters with high education/university students have high understanding of political education, while the voters with junior or senior high school education level also had high understanding with higher percentage, namely $52,43 \%$. This means that the level of formal education does not directly affect the understanding of beginner voter to political education. Understanding of political education can be obtained from various media such as from the results of research [17] in the context of elections, an understanding to the power of mobilization is very important. Research on election campaigns and civil society organization campaigns [18], [19], explained that by building community spaces, it would encourage supporters to join those spaces, and then try to mobilize those supporters to take action to benefit the interest of the organization and its campaign. This explanation is strengthened by the data in table 1.

Tabel 1.Tests of Between-Subjects Effects

Dependent Variable: Voter Participation

\begin{tabular}{|c|c|c|c|c|c|}
\hline Source & Type III Sum of Squares & df & Mean Square & $\mathrm{F}$ & Sig. \\
\hline Corrected Model & $20,324^{\mathrm{a}}$ & 7 & 2,903 & 4,595 & , 000 \\
\hline Intercept & 251,452 & 1 & 251,452 & 397,928 & , 000 \\
\hline Political Knowledge & 15,898 & 3 & 5,299 & 8,386 & , 000 \\
\hline Level of Education & .356 & 1 & ,356 & ,563 & ,454 \\
\hline $\begin{array}{l}\text { Political Knowledge } \\
{ }^{*} \text { Level of Education }\end{array}$ & ,606 & 3 & ,202 & ,320 & ,811 \\
\hline Error & 82,147 & 130 & ,632 & & \\
\hline Total & 759,000 & 138 & & & \\
\hline Corrected Total & 102,471 & 137 & & & \\
\hline
\end{tabular}

a. R Squared $=, 198$ (Adjusted R Squared $=, 155$ ) 
Table 1 shows that the probability or significance value (Sig.) is 0,000 which means it is smaller than 0.01. Therefore, it can be concluded that null hypothesis $\left(\mathrm{H}_{0}\right)$ is counted, which means that the assumption saying that there is the data on the quality of the participation of beginner voters in general election which has unequal variance is acceptable. Based on the test results, it is known that the significance value (Sig.) obtained for understanding to political education is 0,000 , which means it is smaller than 0,01 . Thus the null hypothesis $\left(\mathrm{H}_{0}\right)$ is rejected. It shows that there are differences in the quality of political participation of beginner voters with the level of understanding of political education. Furthermore, the significance value (Sig.) obtained for the education level of the beginner voters is 0,454 , which means it is greater than 0,01 . This means the null hypothesis $\left(\mathrm{H}_{0}\right)$ is accepted. It shows that there is no difference in the quality of political participation of beginner voters in general elections with their level of education. Significance value (Sig.) obtained for an understanding of political education at *the level of education is 0,811 which means it is greater than 0,01 . Thus the null hypothesis $\left(\mathrm{H}_{0}\right)$ is accepted. It shows that there is no interaction of understanding of political education and the level of education of beginner voters in influencing the quality of political participation. The results of this study are in line with the

\section{REFERENCES}

[1] Pebriyenni., Azwar Ananda, Nurhizrah Gistituati. (2018). Role of Political Educa tion in Improving Public Participation in Election: The Case of West Sumatera Governor Election.International Journal of Engineering \& Technology, 7(4.9). (20180104107 DOI: 10.14419/ijet.v7i4.9.20628.

[2] Ahmad Saeed, Mudasir Mustafa, Ahsan Ullah, Muhammad Shoaib, Muhammad Mushtaq and Wasif Ali. (2016). Role of types of electoral rigging, socioeconomic status, politics and voting behavior in formation of attitude towards electoral integrity.Transforming Government: People, Process and Policy, DOI. 10.1108/TG-08-2015-0034. findings of the research of [1] in which political education can be carried out through a voluntary dialogue process between the voters and the political parties, so that the beginner voters can have an awareness of democracy. The level of political awareness is reflected in the number of people taking part in the electoral process [20].

\section{CONCLUSIONS}

From the results of this research it can be concluded that out of 138 respondents, 47,10\% of whom had managed to have high understanding on political education, whle $15,21 \%$ thereof were in low understanding category. The level of formal education does not directly affect the level of understanding to political education, and the level of formal education does not affect the participation quality of the beginner voters in general elections. This finding certainly needs to be further examined so that appropriate models and strategies for political education for beginner voters can be found, and eventually the quality of elections can be improved.

\section{ACKNOWLEDGMENTS}

The authors would like to thank to University of Bung Hatta, General Election Commissions of Padang City, West Sumatera Province, proof-readers, and any other individuals who have helped this research.

[3] General Election Commission. (2019) reflection of the 2019 elections and preparation for the elections 2020. Retrieved from https://news.detik.com/ berita/d4868654/ evaluasi-pemilu-2019kpu.

[4] Election Supervisory Body. (2019). Retrieved from https://www.cnnindonesia .com/nasional/ 20190528205850-32-399276.

[5] Handoyo Eko, Puji Lestari. (2017). Political Education. Yogyakarta: Pohon Cahaya.

[6] Cohen, C. \& Kahne, J. (2012). Participatory Politics: New Media and Youth Political Action. Oakland, CA: YPP Research Network. Retrieved from http://ypp.dml 
centralet/sites/all/files/publications/YPP S urvey Report Full.pdf

[7] Halking. (2018). Aspects of Political Education in the Life of Democracy in Creating Smart Citizenship and Good Citizenship. UNNES, 4(3).

[8] Azwar Ananda, Junaidi and Pebriyenni. (2019). The Awareness of Lecturers and Students of Civic and Pancasila Education (CPE) Toward Public Policy and Public Life in Kota Padang West SumateraIndonesia in The First International Conference on Education, Science and Training: Empowering Educational Human Resources for Global Competitiveness. KnE Social Sciences, pp 260272. DOI 10.18502/kss.v3i15.4372.

[9] Dieter Roth. (2009). Studi Pemilu Empiris: Sumber,Teori-teori, Instrumen dan Metode. Jakarta:Lembaga Survei Indonesia.

[10] Jocelyn A.J. Evans. (2004). Voters and Voting. London: Sage Publications.

[11] Yustiningrum RR Emilia dan Wawan Ichwanuddin. (2015). Political Participation and Voting Behavior in the 2014 Election. Journal of Political, 12(1), pp. 117135.

[12] Ales Kudrnac and Pat Lyons. (2018). Political Inequality among Youth: Do Discussions Foster a Sense of Internal Political Efficacy? Sage Publications and YOUNG Editorial Group SAGE Publications DOI: 10.1177/1103308817738 847.

[13] Darren G. Lilleker \& Karolina KocMichalska. (2016). What Drives Political Participation? Motivations and Mobilization in a Digital Age Political Communi- cation, DOI: 10.1080/10584609.2016.1225 235 ISSN: 1058-4609 (Print) 1091-7675 (Online) Journal.

[14] Elly M. Setiadi, dan Usman Kolip. (2013). Introduction to Political Sociology. Jakarta: Prenada Group.

[15] Ike Atikah Ratnamulyani and Beddy Iriawan Maksudi. (2018). The Role of Social Media in Increasing Beginner Voter Participation Among Students in Bogor Regency.Sosiohumaniora, 20(2), pp. 154-161 ISSN 1411 - 0903 : eISSN: 2443-2660.

[16] Wardhani Primandha Sukma Nur. (2018). Political Participation of Beginner Voters in General Elections, Journal Unimed,ISSN 2407-7429.

[17] Lilleker, D. G. (2013). Empowering the citizens? Political communication, coproduction and the harnessed crowd. In R. Scullion, R. Gerodimos, D. Jackson, \& D. Lilleker (Eds.), The media, political participation and empowerment (pp. 2438). London, UK: Routledge.

[18] Guo, C., \& Saxton, G. (2014). Tweeting social change: How social media are changing nonprofit advocacy. Nonprofit and Voluntary Sector Quarterly, 43(1), pp. 57-79. doi:10.1177/08997 64012471585.

[19] Enjolras, B., Steen-Johnsen, K., \& Wollebæk, D. (2013). Social media and mobilization to offline demonstrations: Transcending participatory divides? New Media E Society, 15(6), pp. 890-908. doi:10.1177/1461444812462844.

[20] Tsai-Wei Sun. (2015). Governing Singapore. Asian Education and Development Studies, 4(3), pp.282-298 DOI:10.1108/ AEDS-11-2014-057. 